\title{
Kultura fizyczna w reedukacji osób odbywających karę pozbawienia wolności - motywacja skazanych do udziału w programach z zakresu kultury fizycznej i sportu
}

\begin{abstract}
In studies seeking motivated prisoners to physical activity while serving sentence in prison, were used the questionnaire methods. Researches group were the men who are physical active $(\mathrm{N}=121)$, aged 22 to 55 years. Most of the respondents were men with primary or secondary, and vocational education (over $90 \%$ ). The results showed that the most important role in participating in physical exercise in prison is motivation to maintain contentment and satisfaction with life, and exercises are primarily a form of entertainment and meaningful full time. Important themes are also making exercise motives maintain contact with a wider group of people. However, inmates differ significantly in terms of motivation to participate in activities depending on the type of physical exercise.
\end{abstract}

\section{Key words:}

physical education, prison, reeducation, motivation

1 Anetta Jaworska, Zakład Pedagogiki Społecznej i Resocjalizacji, Instytut Pedagogiki i Pracy Socjalnej Akademii Pomorskiej w Słupsku, Polska, jaworska.anetta@gmail.com. 


\section{WPROWADZENIE}

Roli motywacji w procesie reedukacji osób pozbawionych wolności nie sposób jest zakwestionować. Szczególne znaczenie należy tu przypisać motywacji autonomicznej, pobudzającej do samodzielnego podejmowania działań na skutek wewnętrznej potrzeby zmiany. Odróżnić należy ją od motywacji instrumentalnej, skupiającej się jedynie na celach zewnętrznych. Samo pojęcie motywacji (łac. motivus-tae) oznacza w języku polskim „skłaniający do ruchu”, a zatem wyznacza ona kierunek działania człowieka i ukierunkowuje go na osiągnięcie postawionych celów, obejmując zarówno proste, jak i złożone mechanizmy zachowań człowieka (Strelau, Jurkowski, Putkiewicz, 1975; Łukaszewski, 2000). Analizując literaturę przedmiotu w zakresie motywacji, Jan Stanik (2013) zwraca uwagę, że funkcjonujące w opracowaniach naukowych definicje motywacji można uporządkować na podstawie czterech podstawowych kryteriów: mechanizmów uruchamiających działanie podmiotu, mechanizmów odpowiedzialnych za kontynuowanie działania, mechanizmów warunkujących zaniechanie działania oraz mechanizmów dotyczących oceny wyniku podjętych czynności. Dokonując przeglądu teorii motywacji (Stanik, 2013), uwzględnia szerokie spektrum podejść teoretycznych:

a) podejście ewolucjonistyczne: traktujące motywację jako gotowość wykazywania trwałych wzorców zachowań, uwarunkowaną instynktem biologicznym lub też potrzebą rozpatrywania własnych genów;

b) podejście psychoanalityczne: związane z czterema obszarami, do których należą: biologiczne stany organizmu człowieka (energia), popędy (instynkty stanowiące napęd działania), motywacja nieświadoma oraz mechanizm dotyczący redukcji napięcia;

c) podejście behawiorystyczne, w którym prawdopodobieństwo podjęcia zachowania jest uzależnione od systemu wzmocnień i stanowi wypadkową popędów, pobudek oraz pozytywnych i negatywnych wzmocnień;

d) podejście oparte na pojęciu potrzeb i wartości, w którym siłą napędowa ludzkiego działania jest poszukiwanie sensu istnienia i indywidualne dla każdego człowieka wartości oraz potrzeb, wśród których najbardziej znanym podziałem jest ten na potrzeby niedoboru i potrzeby wzrostu;

e) podejście poznawcze: oparte na pojęciach informacji, detekcji i inferowaniu konstruktu (przetwarzaniu informacji).

Wśród źródeł wyznaczających kierunki ludzkiej aktywności znajdują się trzy podstawowe motywy (Kocowski, 1993): system ludzkich potrzeb, zadania stawiane przez innych ludzi oraz zadania stawiane przez człowieka samemu sobie. System ludzkich potrzeb łączy się z potrzebami antagonistycznymi, które 
pozwalają uniknąć zarówno niedoboru, jak i nadmiaru określonych stanów (np. jedzenia, ciepła, towarzystwa, ruchu). Owe naturalne motywy mogą być dodatkowo klasyfikowane w postaci: a) motywacji biofunkcjonalnych (utrzymanie życia, zdrowia i bezpieczeństwa); b) motywacji rozwojowych (podejmowanie aktywności rozwojowych, niezwiązanych z zagrożeniem, np. poznawczej, intelektualnej, twórczej); c) motywacje prokreacyjne (np. opiekuńcze, wychowawcze); d) motywacje socjofunkcjonalne (np. powiązań społecznych, utrzymywania pozycji wśród ludzi, mogą obejmować motywacje altruistyczne i prospołeczne, ale także motywacje agresji i dominacji); e) motywacje psychofunkcjonalne (np. zabawa, estetyka, kultura, sens życia i zadowolenie z życia).

\section{MOTYWACJA DO PODEJMOWANIA I UCZESTNICZENIA W KULTURZE FIZYCZNEJ}

Motywacja stanowi stan gotowości do podejmowania, ukierunkowania i podtrzymywania działania, a także do jego zakończenia (Strelau, Doliński, 2011). Należy pamiętać, że najczęściej innymi motywami kierujemy się, podejmując jakąś czynność, a innymi kiedy decydujemy się na jej kontynuowania (Franken, 2006). Tak np. w przypadku podejmowania decyzji o bieganiu ludzie mogą kierować się np. motywami polepszenia zdrowia, samopoczucia lub wyglądu. Podjęcie działania nie jest jednak jednoznaczne z jego kontynuowaniem, o czym świadczy zjawisko nazwane przez Roberta Frankena fenomenem postanowień noworocznych (Franken, 2006, s. 79). Ludzie często podejmują działania dotyczące aktywności fizycznej, które bywają jednak krótkotrwałe - do czasu opadnięcia pierwszego zapału.

Zrozumienie źródeł podejmowania przez ludzi działań z zakresu kultury fizycznej (KF) najbardziej klarownie jest określone przez teorię autodeterminacji (self-determination theory) (Ryan, Deci, 2002, 2007). Wg tej teorii motywacja może być umiejscowiona na kontinuum rozciągającym się pomiędzy skrajnie odmiennymi biegunami (pomijając w tym wypadku element amotywacji - braku motywacji wiążącej się z bezradnością): od motywacji całkowicie zewnętrznej (instrumentalnej) do przeciwstawnej jej - regulacji wewnętrznej (autonomicznej). Autorzy teorii autodeterminacji twierdzą, że ludzie mają wrodzoną skłonność do osobistego rozwoju, którego integralną częścią jest autonomiczna regulacja zachowania. W ramach tej teorii zakłada się, że motywacja wewnętrzna prowadzi do lepszego dostosowania, dobrobytu psychologicznego (well-being), podczas gdy motywacja zewnętrzna wiąże się z gorszą regulacją psychiczną oraz złym samopoczuciem. Teoria ta została potwierdzona licznymi badaniami (Ryan, Deci, 2002). 
W teoriach motywacji postuluje się zatem istnienie kilku rodzajów motywacji, które różnią się stopniem samostanowienia (Lacroix, Perreault, 2012). Motywacja wewnętrzna jest formą najbardziej adaptacyjną, wynikająca ze zinternalizowania podejmowanych zachowań (uznanie ich celu za właściwy i istotny z punktu widzenia jednostki), podczas gdy motywacja zewnętrzna jest regulowana przez potrzebę zaspokojenia innych ludzi. Teoria autodeterminacji zakłada, że jedynie motywacja typu wewnętrznego ma zdolność do wywoływania pozytywnych afektów oraz długotrwałego kontynuowania zachowania. Kiedy inspiracją do podejmowania KF jest motywacja wewnętrzna, aktywność ta staje się dla człowieka źródłem przyjemności i satysfakcji z podejmowanych działań, pociąga za sobą przyrost wiedzy, pożądanego pobudzenia i przyjemności (Jowett i in., 2013). Motywacja zewnętrzna jest natomiast przejawiana wówczas, gdy motywem podjęcia zachowania jest chęć uzyskania nagrody lub uniknięcia negatywnych konsekwencji (Sweet i in., 2012). Innymi słowy - motywacja wewnętrzna jest ukierunkowana na osiągnięcie satysfakcji, zewnętrzna zaś na określony wynik. Z badań wiadomo także, że sportowcy zdeterminowani zewnętrznie zażywają więcej substancji psychoaktywnych, niedozwolonych środków stymulujących oraz alkoholu w porównaniu z osobami ćwiczącymi na skutek motywacji wewnętrznej (Rockafellow, Saules, 2006). Liczne badania wykazały pozytywne korelacje pomiędzy motywacją wewnętrzną a kontynuowaniem ćwiczeń fizycznych oraz ich intensywnością (Ullrich-French, Cox, Bumpus, 2013). Badania Lipowskiego (2005) wskazują natomiast, że dobrym wskaźnikiem motywacyjnym do podejmowania i kontynuowania ćwiczeń jest zadowolenie. Badania te prowadzone na populacji polskich kobiet wykazały, że zadowolenie z wykonywanych ćwiczeń stanowi nagrodę tak istotną, że kobiety powracają do tych czynności po kilku dniach, lub nawet kilku godzinach. Dobrym źródłem motywacji okazała się w badaniach Autora także celowość podejmowanej rekreacji ruchowej. Przewidywany efekt ćwiczeń stanowi bowiem źródło emocji pozytywnych. Największa wytrwałością w wykonywaniu ćwiczeń charakteryzowały się kobiety, których działanie było celowe i odznaczała je wysoka ważność celu, wysokie oczekiwanie oraz przeciętny konflikt pomiędzy oczekiwanym wynikiem a poczuciem możliwości jego osiągnięcia. Badania Lipowskiego pokazały jednak także, że uczestnictwo w rekreacji ruchowej nie zawsze jest działaniem celowym. Najczęstszymi motywami rekreacji ruchowej okazała się chęć poprawy sylwetki i kondycji, nie zaś zdrowie ogólne. Znaczna liczba badań dokumentuje jednak pogląd, że najczęstszym motywem podejmowania przez ludzi aktywności fizycznej (niezależnie od ich wieku) jest właśnie chęć poprawy zdrowia (Borzucka i Rektor, 2005; Parnicka, 2003). Czy ten sam motyw przyświeca osobom odbywającym karę pozbawienia wolności? 


\section{OSOBY BADANE I PROCEDURA BADAŃ}

Poniższa analiza obejmuje wycinek badań dotyczących roli aktywności fizycznej w reedukacji społecznej mężczyzn odbywających karę pozbawienia wolności. Badania przeprowadzono na terenie 16 jednostek penitencjarnych przy pomocy funkcjonariuszy służby więziennej, w ramach działalności Polskiego Towarzystwa Penitencjarnego. Procedura badania poprzedzona była celowym doborem próby badawczej. Funkcjonariusze byli proszeni o wytypowanie skazanych biorących regularny (co najmniej roczny) udział w zajęciach sportowych, a następnie o celowe dobranie grupy podobnej pod względem takich zmiennych, jak: wiek, długość wyroku, wykształcenie, stan zdrowia i aktywność zawodowa. Ostatecznie badaniami objęto 249 skazanych mężczyzn w wieku od 22 do 55 lat. Wśród badanych 128 osób przejawiało w jednostkach penitencjarnych regularną aktywność fizyczną, (potwierdzoną udziałem w zajęciach sportowo-rekreacyjnych) od co najmniej roku. Z uwagi na przedmiot zaprezentowanego poniżej wycinka badań (motywację do podejmowania aktywności fizycznej) w poniższej analizie uwzględniono jedynie grupę osadzonych aktywnych fizycznie. Jako czynnik podziału grup uczyniono rodzaj aktywności fizycznej (AF), w której biorą udział osadzeni.

W analizowanych poniżej badaniach jako predykatora (zmienną niezależną) przyjęto motywację, zmienną wynikową zaś aktywność fizyczną (AF). Związki i korelacje pomiędzy zmiennymi kontrolowano uwzględniają takie zmienne pośredniczące, jak:

- czas do końca wyroku: poniżej i powyżej dwóch lat;

- czas pobytu w jednostce penitencjarnej: kary średnioterminowe i długoterminowe;

- wykształcenie: podstawowe/gimnazjalne, zawodowe, średnie;

- przeszłość kryminalną: pierwszy raz karany/recydywista penitencjarny;

- wiek: wyrażany liczbą lat życia;

- stan zdrowia: operacjonalizowany na podstawie deklaracji skazanego o aktualnym stanie zdrowia oraz pytaniami o przebyte choroby i uzależnienia;

- aktywność zawodową: operacjonalizowana na podstawie deklaracji podejmowania zatrudnienia na okres nie mniejszy niż 3 miesiące w ciągu ostatniego roku (ze względu na deficytowość dostępu do zatrudnia dla osób skazanych, a jednocześnie fakt, że praca stanowi wartościowe źródło sensownego zagospodarowania czasu skazanym, zmienna ta wydawała się także istotnym czynnikiem mogącym wpływać na poziom zmiennych wynikowych).

Zmienne te zostały wyodrębnione jako zmienne kontrolne z uwagi na ich relacje ze zmiennymi wynikowymi. 


\section{PROBLEMY I HIPOTEZY BADAWCZE}

Celem badań było poszukiwanie motywów, którymi kierują się skazani uczestniczący w zajęciach z zakresu kultury fizycznej i sportu lub ćwiczący samodzielnie w czasie wolnym. W tym zakresie postawiono dwa problemy badawcze:

P.1: Jakie rodzaje motywów wyznaczają aktywność fizyczną mężczyzn odbywających karę pozbawienia wolności?

P.2: Czy istnieją różnice w rodzajach motywacji do podejmowania aktywności fizycznej w zależności od preferowanej w zakładzie karnym dyscypliny sportu?

Przewidywano, że:

H.1: Do najważniejszych rodzajów motywów determinujących aktywność fizyczną mężczyzn odbywających karę pozbawienia wolności będą należały: motywacje biofunkcjonalne (zaspokojenia naturalnej potrzeby ruchu i rozładowania napięcia), a w dalszej kolejności motywacje rozwojowe (poprawa kondycji fizycznej, wyglądu i ogólnej sprawności, kształtowanie tożsamości osobowej); motywacje socjofunkcjonalne (w tym: utrzymywania więzi społecznych i kształtowanie tożsamości społecznej, ale także motywacje związane z potrzebą dominacji - ćwiczenie w celu budowania/wzmacniania potencjału do zachowań agresywnych) oraz motywacje psychofunkcjonalne (osiąganie dobrego samopoczucia, rozrywka, dążenie do autonomii i niezależności, umacnianie poczucia własnej wartości).

H.2: Z uwagi na odmienny charakter ćwiczeń oraz odmienne efekty fizyczne i społeczne różnych dyscyplin sportu można przypuszczać, że uwięzieni mężczyźni będą kierowali się odmiennymi pobudkami do podejmowania ćwiczeń w zależności od preferowanej dyscypliny sportu. Zakładam, że motywacja skazanych ćwiczących na siłowni i uprawiających boks będzie w większym stopniu wynikała z celów instrumentalnych (takich jak np. zwiększenie siły mięśni i poprawa sprawności w celach wzmacniania potencjału agresywnego) niż skazanych uczestniczących w innych rodzajach zajęć z zakresu kultury fizycznej.

W pracy tej motywacja nie jest traktowana jako stała struktura osobowości (wyznaczająca ogólny kierunek ludzkiej aktywności), lecz jako aktualny stan wywołujący konkretne zachowania w określonym kontekście sytuacyjnym. 
Przedmiotem zaprezentowanych poniżej badań nie jest zatem ogólna tendencja motywacyjna, lecz szczegółowe motywy, jakie kierują skazanymi w podejmowaniu aktywności fizycznej w warunkach pobytu w zakładzie karnym. Zaprezentowane badania nie odpowiedzą zatem na pytanie, czy podejmowanie aktywności fizycznej stanowi ważny cel życiowy skazanych oraz stałą tendencję ich zachowania, a jedynie jakie rodzaje motywacji pobudzają ich aktywność w warunkach izolacji penitencjarnej. Motywy będą rozumiane za Ossowską (za: Putkiewicz, 1989) w rozumieniu szerokim, jako czynniki wyznaczające zachowanie i pobudzające do działania.

\section{NARZĘDZIE BADAWCZE: KWESTIONARIUSZ MOTYWACJI DO PODEJMOWANIA AKTYWNOŚCI FIZYCZNEJ - WŁASNEGO AUTORSTWA}

W celu zbadania motywacji do uczestnictwa w zajęciach zakresu kultury fizycznej i sportu skonstruowano Kwestionariusz Motywacji (M). Kwestionariusz stanowi 5-czynnikowe narzędzie służące do pomiaru rodzaju motywacji, jaka przyświeca skazanym biorącym regularny udział w zajęciach z zakresu kultury fizycznej i sportu. Poszczególne czynniki mierzą określone rodzaje motywacji. W ich skład wchodzą twierdzenia: motywacja biofunkcjonalna: 1,3,14; motywacja rozwojowa: 7,9,10,17; pozytywna motywacja socjofunkcjonalna: 6,11,13; negatywna motywacja socjofunkcjonalna: 4,15; motywacja psychofunkcjonalna: 2,5,8,12,16.

Za każdą odpowiedź w skali można otrzymać od 1 do 4 pkt., tak że odpowiednio: w zakresie motywacji psychofunkcjonalnej można otrzymać od 5 do 20 pkt.; podobnie w obrębie całego czynnika motywacji socjofunkcjonalnej. Przeprowadzenie analizy czynnikowej metodą Varimax wykazało jednak, że korzystniej będzie podzielić ten czynnik na dwa odrębne czynniki - mierzące socjofunkcjonalną motywację prospołeczną i antyspołeczną. Ostatecznie w zakresie czynnika motywacji socjofunkcjonalnej-pozytywnej oraz motywacji biofunkcjonalnej, w skład których wchodzą po trzy itemy można otrzymać od 3 do 12 pkt., na motywację rozwojową składają się cztery itemy, w obrębie których można otrzymać od 4 do 16 pkt., a w przypadku motywacji socjofunkcjonalnej - negatywnej od 2 do 8 pkt. Im wyższy wynik osiągnięty w skali, tym wyższy poziom badanego rodzaju motywacji.

Pierwszy wyodrębniony czynnik zawiera twierdzenia diagnozujące motywację biofunkcjonalną. Czynnik ten wyjaśnia 26,32\% ogółu wariancji ocen. Rzetelność tego wymiaru wyliczona przy zastosowaniu wielowymiarowej techniki eksploracyjnej - analizy rzetelności pozycji alfa Crombacha $=0,67$. Drugi czynnik, 
mierzący motywację rozwojową, wyjaśnia 18,41\% wariancji ocen, a jego rzetelność wynosi alfa Crombacha = 0,73. Czynnik trzeci, diagnozujący pozytywną motywację socjofunkcjonalną, wyjaśnia natomiast nieco ponad 14\% wariancji ogółu ocen, a jego rzetelność wynosi alfa Crombacha = 0,61. Rzetelność czynnika czwartego: negatywnej motywacji socjofunkcjonalnej wynosi alfa Crombacha = 0,66, a wyjaśnia on 12,3\% wariancji. Ostatni czynnik obejmuje diagnozę motywacji psychofunkcjonalnej. Wyjaśnia on około 11,42\% wariancji ocen i posiada rzetelność alfa Crombacha $=0,72$.

\section{WYNIKI}

W celu zweryfikowania hipotezy o różnicach w poziomie odmiennych typów motywacji w zależności od rodzaju zajęć sportowych lub samodzielnego ćwiczenia w celi zastosowano jednoczynnikową analizę wariancji dla prób niezależnych ANOVA $^{2}$.

Wyniki analizy wykazały, że grupy nie różnią się między sobą pod względem motywacji biofunkcjonalnej $F(5,158)=1.44, p=0.215$. Poziom motywacji biofunkcjonalnej na średnim poziomie $M=8.45$ ( $S D=1.92$ ) oznacza, że w stopniu wyższym niż przeciętny, więźniami podejmującymi aktywność sportową w zakładzie karnym kierują motywy związane z koniecznością zaspokajania podstawowych potrzeb biofizjologicznych. Niezależnie od rodzaju zajęć skazani wykazujący aktywność fizyczną wyrażali zdanie, że w znacznym stopniu, motywami, jakimi kierują się, podejmując ćwiczenia są: potrzeba ruchu, potrzeba rozładowania stresu, złości, napięć i rozładowania nadmiaru energii.

Brak istotnych różnic statystycznych pomiędzy grupami skazanych wystąpił także $\mathrm{w}$ obszarze motywacji rozwojowej $\mathrm{F}(13,150)=0.983$, $\mathrm{p}=0.43$. W zakresie tego rodzaju motywacji skazani osiągnęli średni wynik $M=11.49$ ( $S D=6.02)$, który oznacza raczej wysoką tendencję wykazywania motywów rozwojowych, wśród których wymieniano: poprawę wyglądu, poprawę kondycji fizycznej i ogólnej sprawności. Relatywnie niskie wyniki w obszarze tego rodzaju motywacji pojawiły się w zakresie poprawy lub polepszania stanu zdrowia.

Kolejnym analizowanym rodzajem motywacji była motywacja socjofunkcjonalna w jej prospołecznym znaczeniu. W obszarze tej motywacji badana grupa więźniów osiągnęła średni wynik $M=8.02$ ( $S D=2.81)$. Motywacja ta nie różnicowała aktywnych fizycznie skazanych ze względu na rodzaj uprawianej

2 W opracowaniu analiz statystycznych wykorzystano oprogramowanie IBM SPSS Statistics 20. 
dyscypliny sportu $F(11,152)=2.01, p=0.08$. Uplasowany na średnim poziomie (niewiele ponad 8 pkt.) poziom tej motywacji oznacza przeciętną tendencję do podejmowania wysiłku fizycznego z takich powodów, jak: chęć bycia szanowanych dzięki sportowi, chęć pokazanie innym swoich dobrych stron czy też chęć przebywania z innymi ludźmi.

Znaczące różnice w zakresie poziomów motywacji, w zależności od uprawianej dyscypliny aktywności fizycznej, wystąpiły natomiast w zakresie dwóch kolejnych rodzajów motywacji: socjofunkcjonalnej-negatywnej oraz psychofunkcjonalnej. Szczegółowe wyniki tych analiz znajdują się w tabelach 1 i 2 oraz na rysunkach 1 i 2, obrazujących wyniki uzyskane po zastosowaniu testów post-hoc.

Tabela 1. Istotność różnic w poziomie motywacji socjofunkcjonalnej-negatywnej w zależności od rodzaju podejmowanej aktywności fizycznej ( $\mathrm{N}=164)$

\begin{tabular}{|c|c|c|c|c|}
\hline Rodzaj aktywności fizycznej & $\mathbf{M}$ & SD & $\mathbf{F}$ & Istotność \\
\hline gry zespołowe & 4.67 & 1.43 & 7.118 & $\mathrm{p}<0.001$ \\
\hline bieganie & 4.25 & 2.31 & & \\
\hline tenis stołowy & 4.25 & 2.31 & & \\
\hline siłownia & 6.46 & 2.03 & & \\
\hline sporty walki & 6.27 & 2.33 & & \\
\hline ćwiczenia w celi & 5.18 & 2.19 & & \\
\hline
\end{tabular}

Źródło: Opracowanie własne.

W tabeli 1 zaprezentowano wyniki jednoczynnikowej analizy wariancji, wskazujące na istotne różnice w poziomie negatywnej motywacji socjofunkcjonalnej. Istotny statystycznie efekt zmiennej motywacja socjofunkcjonalna-negatywna $\mathrm{F}(6,157)=7.118,(\mathrm{p}<0.001)$ wskazuje, że mężczyźni uprawiający różne rodzaje sportu w zakładzie karnym różnią się w zakresie antyspołecznej motywacji do podejmowanych zachowań sportowych. Obszar negatywnej motywacji socjofunkcjonalnej obejmuje takie rodzaje motywów, jak: chęć dominacji oraz wzmacnianie siły mięśni w celach agresywnych i antyspołecznych, potrzeba zwiększenia siły w celu walki z wrogami oraz chęć wzbudzania w innych ludziach respektu przez siłą mięśni.

Przeprowadzono porównania post-hoc pomiędzy wszystkimi grupami (zob. rys.1). Zestawienie średnich pokazuje (zob. tab. 1), że najwyższy poziom motywacji socjofunckjonalnej negatywnej prezentują skazani uczestniczący w zajęciach na siłowni $(M=6.46)$ oraz uprawiający boks $(M=6.27)$. Poziom motywacji socjofunkcjonalnej-negatywnej uczestników obu wymienionych rodzajów dyscyplin sportowych był istotnie wyższy niż wśród wszystkich pozostałych osób 
ćwiczących (ps<0.05), a jednocześnie nie różnił on grupy ćwiczących na siłowni i uprawiających boks ( $\mathrm{p}=0.78$ ). Warto odnotować, że najniższy poziom motywacji socjofunkcjonalnej-negatywnej wykazali mężczyźni uprawiający w zakładzie karnym biegi oraz tenis stołowy $(M=4.25)$, a w dalszej kolejności gry zespołowe $(M=4.67)$ oraz ćwiczenia w celi $(M=5.18)$. Pomiędzy tymi grupami nie wystąpiły istotne różnice w poziomie omawianego rodzaju motywacji.

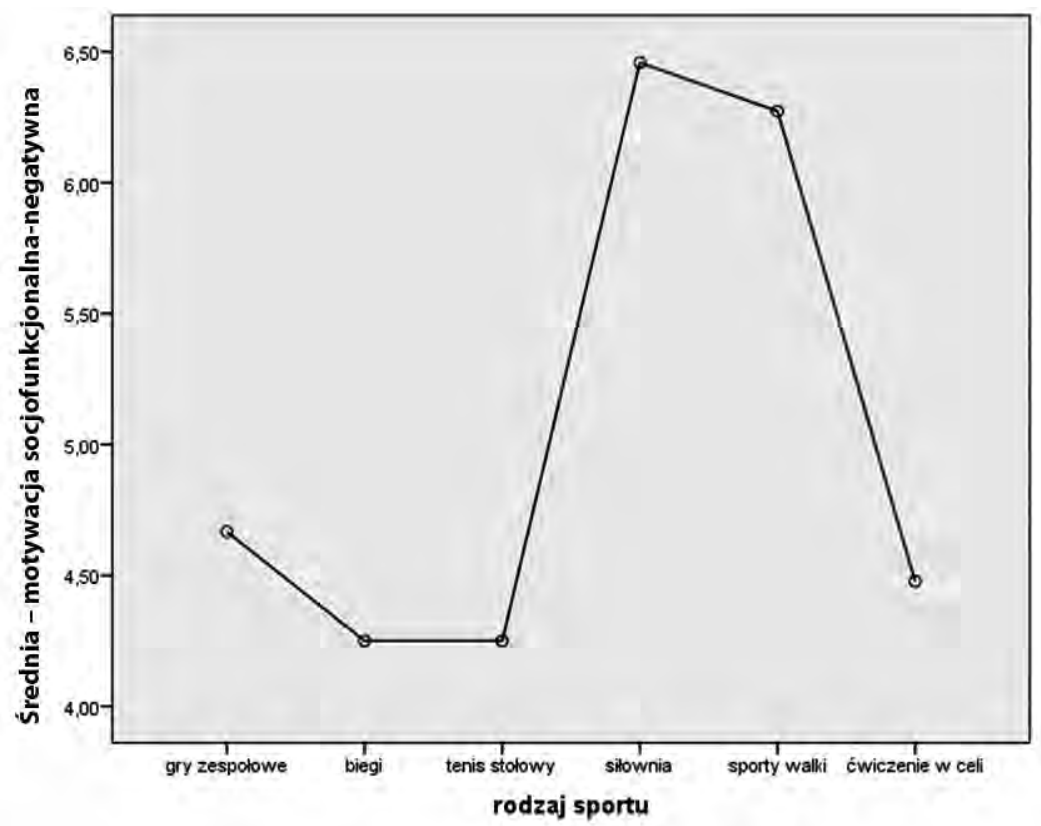

Rys. 1. Analiza porównań wielokrotnych w zakresie motywacji socjofunkcjonalnej-negatywnej Źródło: Opracowanie własne.

Tabela 2. Istotność różnic w poziomie motywacji psychofunkcjonalnej w zależności od rodzaju podejmowanej aktywności fizycznej

\begin{tabular}{lcccc}
\hline Rodzaj aktywności fizycznej & $\mathbf{M}$ & SD & F & Istotność \\
\cline { 1 - 3 } gry zespołowe & 15.00 & 2.38 & \multirow{2}{*}{18.46} & $\mathrm{p}<0.001$ \\
\cline { 1 - 3 } bieganie & 13.13 & 5.51 & & \\
\cline { 1 - 3 } tenis stołowy & 14.75 & 2,43 & & \\
\cline { 1 - 4 } siłownia & 8.40 & 3.75 & & \\
\cline { 1 - 3 } sporty walki & 11.36 & 4.06 & & \\
\hline ćwiczenia w celi & 14.14 & 3.59 & & \\
\hline
\end{tabular}

Źródło: Badania własne. 
Wartości różnicujące badane grupy ujawniła natomiast analiza wariancji wykonana w celu porównania poziomów motywacji psychofunkcjonalnej $\mathrm{F}(16,147)=18.462(M=12.38 S D=4.45), \mathrm{p}<0.001$ (zob. tab.2). Wysoki poziom tego rodzaju motywacji wskazuje na podejmowanie zachowań sportowych z uwagi na chęć polepszenia dobrostanu psychicznego: poczucie estetyki, chęć zabawy, poszukiwanie sensownego sposobu na zapełnienie wolnego czasu, poszukiwanie zadowolenia. Skazani o wysokim poziomie tego rodzaju motywacji deklarowali, że ćwiczenia dają im poczucie niezależności i wolności pomimo pobytu w zakładzie karnym. Motywy związane z tym rodzajem regulacji zachowania były związane z dobrą zabawą, rozrywką, zapobieganiem nudzie, lepszym samopoczucie psychicznym oraz czerpaniem przyjemności z wykonywania ćwiczeń.

Wykonana post-hoc analiza porównań wielokrotnych ujawniła, że najniższym poziomem tego rodzaju motywacji odznaczają się skazani uczestniczący w ćwiczeniach na siłowni $(M=8.40)$, a najwyższym osoby biorące udział w grach zespołowych ( $\mathrm{M}=15.00)$.

Rys. 2 przedstawia zestawienie porównań post hoc dla badanych grup. W wyniku analizy porównań pomiędzy wszystkimi grupami okazało się, że skazani biorący udział w zajęciach na siłowni nie tylko odznaczają się najniższym poziomem motywacji psychofunkcjonalnej, ale poziom ten w sposób istotny statystycznie różnicuje sporty siłowe w porównaniu ze wszystkimi pozostałymi rodzajami zajęć fizycznych. Największa istotność różnic obejmuje porównanie poziomu motywacji psychofunkcjonalnej osób ćwiczących na siłowni z mężczyznami uprawiającymi gry zespołowe $(M=15.00)$ oraz grającymi w tenisa $(M=14.75)$ i ćwiczącymi w celi $(M=14.14)$ ps<0.001, a w dalszej kolejności z osobami uprawiającymi biegi ( $M=13.13), \mathrm{p}=0.001$ oraz uprawiającymi sporty walki $(\mathrm{M}=11.36), \mathrm{p}<0.05$. Istotne różnice wystąpiły także pomiędzy mężczyznami uprawiającymi sporty walki (głównie boks) a pozostałymi grupami ćwiczących więźniów (zob.: tab.6 oraz rys.4), z wyjątkiem grupy skazanych uprawiającymi biegi. Pomiędzy pozostałymi grupami osób ćwiczących nie wystąpiły istotne różnice statystyczne w zakresie motywacji psychofunkcjonalnej.

Kolejnym i ostatnim etapem analizy badań była synteza jakościowych wypowiedzi skazanych w celu wyodrębnienia dwóch typów motywacji: wynikającej z potrzeb niedoboru oraz wynikającej z potrzeb wzrostu. W analizie wypowiedzi o charakterze jakościowym wyodrębniono pierwotnie rodzaje motywacji wewnętrznej - ukierunkowanej na satysfakcję osobistą i zewnętrznej (instrumentalnej) - odznaczającej się uczestniczeniem w zajęciach z zakresu kultury fizycznej i sportu w innych celach niż te wynikające z samego charakteru aktywności fizycznej. Poniżej znajdują się pogrupowane w określone typy motywacji wypowiedzi 


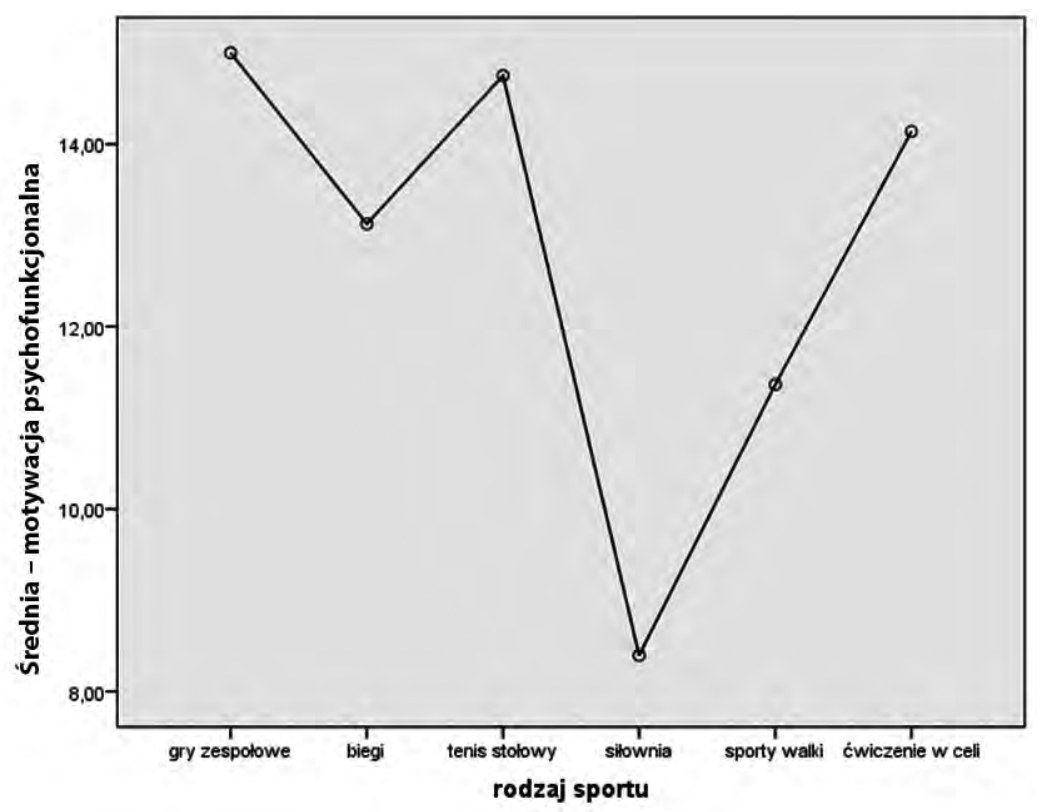

Rys. 2. Analiza porównań wielokrotnych w zakresie motywacji psychofunkcjonalnej Źródło: Opracowanie własne.

skazanych. Z oryginalnych wypowiedzi skazanych usunięto jedynie błędy ortograficzne z uwagi na brak ich znaczenia w prowadzonej analizie.

W zakresie typu motywacji wewnętrznej wyróżniono takie wypowiedzi osadzonych, jak:

a) tendencja do podejmowania działania ze względu na samą treść tej aktywności: lubię ćwiczyć, bo przyjemnie jest biegać; granie jest przyjemne; fajnie się ćwiczy; bo ćwiczenie jest fajne; ćwiczę bo lubię; lubię po prostu; bo mi się chce ćwiczyć; bo mam chęć; lubię w piłkę grać i zawsze lubiłem; bo trzeba się tu ruszać trochę, żeby nie zwariować; bo to więcej ruchu niż siedzieć; bo to rozrywki trochę; zawsze to trochę zabawy; czasem się dobrze bawimy;

b) tendencja do podejmowania działania ze względu na poprawę samopoczucia: bo się lepiej czuję jakoś; mam lepsze samopoczucie; dobrze się czuję po ćwiczeniach; bo ćwiczyłem zawsze i teraz bym się źle czuł; ponieważ lepiej się czuję, jak ćwiczę; lubię ćwiczyć; człowiek się lepiej czuje, jak poćwiczy; żeby się odstresować; żeby taki napięty nie być; bo to mnie rozluźnia; bo chyba by mnie rozsadziło, jakbym nie ćwiczył; 
c) tendencja do podejmowania działania ze względu na poprawę zdrowia: nie chcę się rozchorować przez ten pobyt tutaj; żeby być zdrowy; bo to zdrowe; żeby być sprawny; sprawny chce być; chce być sprawny i dobrze wygladać;

d) tendencja do podejmowania działania ze względu na poczucie kompetencji: czuje, że coś dobrze robię; bo mi to daje satysfakcję, jak coraz lepiej mi idzie; bo jestem w tym dobry; bo dobrze gram w tenisa; bo silny jestem i coraz silniejszy jak stąd wyjdę; jestem najlepszy w piłkę; bo jestem w czymś dobry; żeby pokazać sobie, że coś umiem; po prostu umiem to i lubię; bo czuje, że coś potrafię;

e) tendencja do podejmowania działania ze względu na poczucie autonomii: bo coś dla siebie robię; mogę robić coś innego niż tylko siedzieć; tak wybrałem; to mój wybór; bo mogę coś robić sam; bo jak biegam, to jestem wolny; wolny jestem, jak ćwiczę; bo wtedy myślę o wolności.

W obszarze motywacji instrumentalnej znalazły się takie wypowiedzi skazanych, jak:

a) tendencja do podejmowania działania ze względu na potrzebę opuszczenia celi: częściej się wychodzi z celi; można wyjść z celi; nie siedzi się ciągle w celi; bo nudno; bo się w celi nie jest cały czas; z celi można wyjść; żeby nudno nie było; bo się nudzi;

b) tendencja do podejmowania działania ze względu na brak alternatywy: bo nie ma co innego do roboty; bo nic innego nie ma; bo to najłatwiej było załatwić; bo mało innych programów; nie ma dla mnie programów; bo nie ma pracy, to nie ma co robić; bo mnie do pracy nie wzięli; czas szybciej leci; szybko mija czas i się nie nudzę;

c) tendencja do podejmowania działania ze względu na potrzebę wymiany informacji: można pogadać; trochę dowiedzieć można się co nie tylko co pod cela; ja wiem i inni wiedzq; żeby pogadać; coś się zawsze załatwi więcej; coś się pogada, załatwi; porozmawia się z kim trzeba;

d) tendencja do podejmowania działania ze względu na higienę: prysznic jest; kqpiel, prysznic; żeby iść pod prysznic; można się umyć więcej.

Z powyższych wypowiedzi skazanych obok wyodrębnienia motywacji wewnętrznej i zewnętrznej warto zwrócić uwagę na rodzaje potrzeb zaspokajanych w więzieniu dzięki aktywności fizycznej. Pierwszą i wyraźnie większą grupę stanowią potrzeby niedoboru (wynikające z sytuacji deprywacyjnej). Przytoczone powyżej wypowiedzi osadzonych pozwalają na wyodrębnienie motywacji związanych z takimi potrzebami niedoboru, jak: brak ruchu, brak sensownych zajęć, poczucie niedostatecznej higieny, nadmierne napięcie, brak poczucia autonomii 
oraz niezaspokojona potrzeba szerszych kontaktów społecznych. Wśród potrzeb wzrostu motywujących skazanych do podejmowania i kontynuowania aktywności fizycznej należą natomiast: rozwój zadowolenia i satysfakcji z ćwiczeń, dbałość o dobre samopoczucie, dbałość o zdrowie, kształtowanie tożsamości sportowca. Analizując proporcje wypowiedzi obejmujące potrzeby niedoboru i potrzeby wzrostu motywujące do zachować sportowych w zakładzie karnym, należy zauważyć, że w większym stopniu obejmują one zaburzoną homeostazę (redukcja napięcia i zaspokojenie zdeprywowanych potrzeb) niż elementy rozwojowe. Warto jednak zaznaczyć, że podejmowanie ćwiczeń ze względu na rozwój osobisty (głównie fizyczny oraz tożsamościowy) stanowi także ważny element wypowiedzi wielu skazanych. Ze względu na jakościowy charakter wypowiedzi oraz znaczące braki w wypowiedziach wielu respondentów analiza ta nie jest traktowana jako element rzetelnej weryfikacji hipotezy, lecz stanowi jedynie tło i uzupełnienie zaprezentowanych wcześniej zastawień psychometrycznych.

\section{DYSKUSJA I WNIOSKI}

Zaprezentowane wyniki badań pozwalają na określenie dwóch podstawowych rodzajów motywów do podejmowania aktywności fizycznej przez mężczyzn odbywających karę pozbawienia wolności. Motywacje skazanych obejmują większość motywów, jakimi kierują się ludzie w podejmowaniu zachowań sportowych. Wbrew hipotetycznemu oczekiwaniu o dominującej roli motywów biofunkcjonalnych okazało się, że najważniejszymi motywami podejmowania zachowań sportowych w zakładzie karnym wśród wszystkich skazanych są tendencje związane z potrzebą polepszenia funkcjonowania psychicznego. Okazało się, że skazani biorący udział w zajęciach z zakresu kultury fizycznej i sportu w największym stopniu kierują się chęcią osiągnięcia dobrostanu psychicznego, a w tym poszukiwaniem sensownych sposobów na spędzenie czasu, poczuciem przyjemności i zadowolenia wynikającego z uprawiania ćwiczeń. Jednocześnie okazało się, że w najmniejszych stopniu motywy te stanowią podstawę działań dla skazanych uprawiających sporty siłowe, a w dalszej kolejności sporty walki. Dla mężczyzn uczestniczących w zajęciach na siłowni oraz uprawiających boks najbardziej istotne motywy obejmowały: chęć dominacji oraz wzmacnianie siły mięśni w celach agresywnych i antyspołecznych, potrzebę zwiększenia siły w celu walki z wrogami oraz chęć wzbudzania w innych ludziach respektu przez siłą. Motywy te należałoby uznać za negatywne z punktu widzenia założeń resocjalizacji. 
Ważnym rodzajem motywacji do podejmowania aktywności fizycznej, bez względu na rodzaj uprawianej dyscypliny sportu, okazały się jednak także pozytywne motywy społeczne związane z przemianą tożsamości, takie jak: chęć bycia szanowanych dzięki sportowi, chęć pokazanie innym swoich dobrych/mocnych stron oraz chęć przebywania z innymi ludźmi. Podobny poziom osiągnęły także motywy rozwojowe. Motywacja rozwojowa koncentruje się na dążeniu do określonych celów, wśród których u mężczyzn odbywających karę pozbawienia wolności dominują przede wszystkim: poprawa samopoczucia, poprawa wyglądu oraz poprawa kondycji i sprawności ogólnej. W przeciwieństwie do wielu badań prowadzonych w populacji ludzi wolnych (Borzucka i Rektor, 2005; Parnicka, 2003) wśród skazanych niezwykle rzadko pojawiają się jednak motywy związane z polepszeniem stanu zdrowia. Prawdopodobną przyczyną tej rozbieżności jest fakt, że w badaniach obejmujących populację więzienną brały udział przede wszystkim osoby młode (do 55 roku życia) i w pełni sił fizycznych.

Niezależnie od rodzaju uprawianych ćwiczeń na poziomie przeciętnym skazani wykazali także motywację związaną z koniecznością zaspokajania podstawowych potrzeb biolofizjologicznych: potrzebą ruchu, potrzebą rozładowania stresu, złości, napięć i rozładowania nadmiaru energii. Z uwagi na deprywacyjny charakter kary pozbawienia wolności hipotetycznie zakładano, że motywy te będą stanowiły najważniejszy czynnik wyzwalający podejmowanie i kontynuowanie ćwiczeń, okazało się jednak, że znacznie ważniejszy jest dla osadzonych dobrostan psychiczny. Należy jednak przypuszczać, że deklarowane przez osadzonych, jako motyw podejmowania ćwiczeń, dobre samopoczucie psychiczne jest także powiązane z wywoływaną ćwiczeniami redukcją napięć. Motywy te są zatem powiązane i przenikają się wzajemnie. W przypadku sytuacji niedoboru, jaki towarzyszy osobom pozbawionym wolności, można przypuszczać, że jedną z ważnych form motywacji pobudzającą aktywność fizyczną jest motywacja doznaniowa. Pozostawanie większość czasu w stanie bezruchu wyzwala tendencję do podejmowania działań neutralizujących wynikające z niego napięcie. Z uwagi na małą ilość ruchu uruchomiony zostaje zarówno układ endokrynalny, jak i wegetatywny, skazani poszukują możliwości do opuszczenia celi i wzmożonego ruchu w celu rozładowania napięcia.

Reasumując, mogę stwierdzić, że:

- Najważniejszą rolę odgrywa motywacja do podtrzymywania zadowolenia i satysfakcji z życia, a ćwiczenia stanowią formę rozrywki i sensownego zapełnienia czasu.

- Motywacja ta w mniejszym stopniu stanowi wartość dla osób ćwiczących na siłowni i uprawiających boks. W tych grupach ważne miejsce zajmuje 
niepożądana z punktu widzenia założeń resocjalizacyjnych motywacja zdobywania dominacji i kształtowania potencjału do agresji.

- Ważnymi motywami podejmowania ćwiczeń dla wszystkich skazanych są motywy utrzymywania kontaktów z szerszą grupą ludzi, a także kształtowania tożsamości osobowej sportowca.

- Aktywność sportowa jest podejmowana przez osadzonych także z powodów rozwojowych, głównie rozwoju sprawności i kondycji fizycznej, a w mniejszym stopniu z chęci poprawy zdrowia, co jest sprzeczne z badaniami prowadzonymi w środowisku ludzi wolnych.

- Istotnymi motywami podejmowania ćwiczeń dla wszystkich skazanych (choć nieco mniej ważnymi niż wymienione powyżej) są: potrzeba ruchu, opuszczenia celi, rozładowania, napięć i nadmiaru energii.

Wydaje się, że w sytuacji odbywania kary pozbawienia wolności istotną rolę odgrywają zarówno motywy autonomiczne (podejmowania zachowań sportowych dla satysfakcji z nich płynących: poprawa samopoczucia, poczucie kompetencji, poczucie wolności wyboru poprawa kondycji, sprawności ogólnej, wyglądu, satysfakcja osobista, szersze interakcje społeczne), jak i instrumentalne (częstsza kąpiel, poprawa siły mięśni w celu lepszej wydolności do zachowań przestępczych, możliwość opuszczenia celi, nawiązanie kontaktu z innymi osadzonymi - wymiana informacji). Motywację do podejmowania ćwiczeń nie zawsze można zatem uznać za pozytywną, w wielu wypadkach przyświecają jej jednak cele rozwojowe oraz związane z psychicznym i fizycznym dobrostanem.

Warto pamiętać, że wielu skazanych odbywających karę pozbawienia wolności nie bierze udziału w zajęciach z zakresu kultury fizycznej i sportu, a także nie podejmuje takiej aktywności samodzielnie. Zaprezentowane powyżej badania nie odpowiadają na pytanie, dlaczego tak się dzieje. Sam brak podejmowania działania, a w tym wypadku brak pojmowania aktywności fizycznej w warunkach odbywania kary pozbawienia wolności nie zawsze wynika z braku motywacji. Nie można wykluczyć, że osoby, które nie biorą udziału w zajęciach z zakresu kultury fizycznej i sportu, posiadają motywację do jej podejmowania, jednak przeszkodą do realizacji motywu jest brak energii działania. Z uwagi na fakt, że wśród ludzi występują znaczne różnice indywidualne związane z poziomem aktywacji podstawowej, temperamentem i tzw. wigorem życiowym nie można wykluczyć, że przyczyną braku podejmowania aktywności fizycznej przez znaczącą większość osób odbywających karę pozbawienia wolności są czynniki konstytucjonalne (niski poziom aktywacji podstawowej), a także brak warunków infrastrukturalnych do podejmowania aktywności fizycznej oraz brak (lub niedostateczne) wspierania aktywności fizycznej z zewnątrz (brak zachęcania do aktywności ze strony per- 
sonelu więziennego). Problem braku podejmowania aktywności fizycznej stanowi jednak oddzielny temat i wymaga, jak sądzę, oddzielnych badań empirycznych.

\section{Literatura:}

Franken, R.E. (2006). Psychologia motywacji. Gdańsk: GWP.

Jowett, G.E., Hill, A.P., Hall, H.K., Curran, Th. (2013). Perfectionism and junior athlete burnout: The mediating role of autonomous and controlled motivation. Sport, Exercise, and Performance Psychology, 2 (1), s. 48-61.

Kocowski, T. (1993). Motywacja. W: W. Pomykało. Encyklopedia Pedagogiczna (s. 384-389). Warszawa: Fundacja INNOWACJA.

Lacroix, Ch., Perreault, S. (2012). Dissocier la fréquence de l'intensité des types de motivation dans le sport en regard du modèle hiérarchique de la motivation intrinsèque et extrinsèque. Canadian Psychology. Special issue:Sport and Exercise Psychology, 53 (4), s. 328-333.

Lipowski, M. (2005). Rekreacja ruchowa kobiet: motywy zachowań prozdrowotnych. Gdańsk: Wyd. Uczelniane AWFiS.

Putkiewicz, Z. (1989). Motywy szkolnego uczenia się młodzieży. Warszawa: PZW.

Rockafellow, B.D., Saules, K.K. (2006). Substance use by college students: The role of intrinsic versus extrinsic motivation for athletic involvement. Psychology of Addictive Behaviors, 20 (3), s. 279-287.

Ryan, R.M., Deci, E.L. (2002). An overview of self-determination theory: An organismic-dialectical perspective. W: E.L. Deci, R.M. Ryan (Eds.), Handbook of self-determination research (s. 3-33). Rochester, NY: University of Rochester Press.

Ryan, R.M., Deci, E.L. (2007). Active human nature: Self-determination theory and the promotion and maintenance of sport, exercise, and health. W: M.S. Hagger, N.L.D. Chatzisarantis (Eds.), Intrinsic motivation and self-determination in exercise and sport (s. 1-19). Champaign, IL: Human Kinetics.

Stanik, J.M. (2013). Psychologia sądowa. Warszawa: PWN.

Strelau, J., Jurkowski, A., Putkiewicz, Z. (1975), Podstawy Psychologii dla nauczycieli. Warszawa: PWN.

Strelau, J., Doliński, D. (2011). Psychologia akademicka. Gdańsk: GWP.

Sweet, Sh.N., Fortier, M.S., Strachan, Sh.M., Blanchard, Ch.M. (2012). Testing and integrating self-determination theory and self-efficacy theory in a physical activity context. Canadian Psychology, Special issue: Sport and Exercise Psychology, 53 (4), s. 319-327.

Ullrich-French, S., Cox, A.E., Bumpus, M.F. (2013). Physical activity motivation and behavior across the transition to university. Sport, Exercise, and Performance Psychology, 2 (2), s. 90-101. 


\section{ZAtACCZNIK 1}

\section{KWESTIONARIUSZ M}

Proszę Pana o odpowiedź na poniższe pytanie dotyczące powodów, dla których uczestniczy Pan w zajęciach sportowych podczas odbywania kary. Ważne jest, aby na początku zastanowił się Pan krótko i samodzielnie podał powody, o które pytam.

Mogę powiedzieć, że najważniejsze powody, dla których uczestniczę w zajęciach sportowych to.

Teraz proszę o wypełnienie poniższej tabeli poprzez zaznaczenie w stopniu, w jakim podane tam powody pasują do tych, dla których Pan zajmuje się sportem w zakładzie karnym.

Poszczególne cyfry w tabeli oznaczają:

1 - nie pasuje do mnie

2 - pasuje do mnie w pewnym stopniu

3 - raczej do mnie pasuje

4 - zdecydowanie do mnie pasuje

\begin{tabular}{|l|l|c|c|c|c|}
\hline & $\begin{array}{l}\text { Mogę powiedzieć, że do ważnych powodów, dla których } \\
\text { uczestniczę w zajęciach sportowych należy: }\end{array}$ & $\mathbf{1}$ & $\mathbf{2}$ & $\mathbf{3}$ & $\mathbf{4}$ \\
\hline 1 & potrzeba rozładowania złości, napięcia & & & & \\
\hline 2 & możliwość bycia niezależnym wolnym podczas ćwiczeń & & & & \\
\hline 3 & potrzeba ruchu, którego brakuje w zakładzie karnym & & & & \\
\hline 4 & konieczność nabrania siły do walki z moimi wrogami & & & & \\
\hline 5 & umacnianie poczucia własnej wartości & & & & \\
\hline 6 & chęć bycia szanowanym dzięki sportowi & & & & \\
\hline 7 & poprawa ogólnej sprawności & & & & \\
\hline 8 & przyjemność z ćwiczeń & & & & \\
\hline 9 & poprawa wyglądu & & & & \\
\hline
\end{tabular}




\begin{tabular}{|l|l|c|c|c|c|}
\hline & $\begin{array}{l}\text { Mogę powiedzieć, że do ważnych powodów, dla których } \\
\text { uczestniczę w zajęciach sportowych należy: }\end{array}$ & $\mathbf{1}$ & $\mathbf{2}$ & $\mathbf{3}$ & $\mathbf{4}$ \\
\hline 10 & poprawa kondycji fizycznej & & & & \\
\hline 11 & chęć przebywania z innymi ludźmi & & & & \\
\hline 12 & dobra zabawa/rozrywka i zapobieganie nudzie & & & & \\
\hline 13 & chęć pokazania innym, że coś potrafię & & & & \\
\hline 14 & potrzeba rozładowania nadmiaru energii & & & & \\
\hline 15 & potrzeba wzbudzania w innych respektu przede mną & & & & \\
\hline 16 & lepsze samopoczucie psychiczne & & & & \\
\hline 17 & poprawa zdrowia lub dbałość o zdrowie & & & & \\
\hline
\end{tabular}

